doi: $10.35757 /$ KiS.2019.63.3.7

\begin{tabular}{llr} 
KULTURA & $\begin{array}{l}\text { POLSKA A KADEMIA NAUK } \\
\text { KOMITET SOCJOLOGII }\end{array}$ & ISSN 0023-5172 \\
i & INSTYT T STUDIÓW POLITYCZNYCH & \\
SPOLECZENSTWO & 2019, nr 3 W SETNĄ ROCZNICĘ URODZIN ANTONINY KŁOSKOWSKIEJ \\
\hline
\end{tabular}
$\begin{array}{lllllllllllll}A & R & T & Y & K & U & Ł & Y\end{array}$
I
$\begin{array}{llllllll}\mathrm{R} & \mathrm{O} & \mathrm{Z} & \mathrm{P} & \mathrm{R} & \mathrm{A} & \mathrm{W} & \mathrm{Y}\end{array}$

MICHAŁ CEBULA

Uniwersytet Wroctawski

\title{
MIESZKAŃCY MIASTA W POLU SPOŁECZNYM \\ WZORY UCZESTNICTWA W KULTURZE, SIECI SPOŁECZNE I STRUKTURA KLASOWA
}

\section{MIASTO W OGLĄDZIE KULTUROWYM: GŁÓWNE PERSPEKTYWY TEORETYCZNE}

Jednym z głównych problemów podejmowanych we współczesnych studiach miejskich jest kwestia kultury i konsumpcji, traktowanych jako koło zamachowe wzrostu i rozwoju gospodarczego epoki postfordyzmu, jako sedno miejskiego sposobu życia - obszar kreowania i manifestowania tożsamości, stylów życia, statusu mieszkańców, a zarazem ujawniania interesów i wdrażania miejskich polityk. Zainteresowanie kulturowym wymiarem miast można łączyć z ogólnym „zwrotem” (cultural turn) w naukach społecznych, polegającym na uznaniu kultury za autonomiczny czynnik konstytuujący relacje społeczne i formy życia zbiorowego (Alexander, Bowler 2014, s. 4; Klekotko i in. 2015, s. 17), w tym także w aspekcie ustanawiania, legitymizowania i reprodukowania struktur władzy i dominacji (por. Cebula 2017). Definiowanie fenomenu „miejskości” w kategoriach specyficznego sposobu życia mieszkańców stanowiło wspólny mianownik koncepcji takich klasycznych myślicieli, jak Georg Simmel (2005), Louis Wirth (1938) czy Herbert J. Gans (1962). O ile jednak badacze ci traktowali istotę miejskiego życia całościowo (z jego anoni- 
mowością, wielością form uspołecznienia, poluzowaniem więzi) i wiązali z charakterystyką terytorialną miasta (jego wielkością, gęstością zaludnienia, walorami architektonicznymi itp.) czy składem socjodemograficznym jego mieszkańców (np. ich różnorodnością), o tyle współczesne studia skłonne są w większej mierze akcentować wymiar kulturowy jako niezależny od pozostałych (Klekotko, Navarro 2015) oraz wskazywać na zróżnicowanie stylów życia i praktyk realizowanych w jego obrębie (Błaszczyk 2015; Błaszczyk, Cebula 2016). Spojrzenie na miasto z perspektywy wzorów konsumpcji i praktyk stylów życia jego mieszkańców nie musi jednak oznaczać porzucenia paradygmatu strukturalnego i klasowego. Jak bowiem dowodzi Pierre Bourdieu (2005), to właśnie poprzez style życia tworzone i odtwarzane są nierówności, bariery klasowe, stosunki dominacji. W literaturze z zakresu badań nad miastem „miastotwórczą” funkcję kultury konceptualizuje się na trzy wzajemnie powiązane sposoby:

(a) z perspektywy produkcji kulturowej, w której miasto jest przestrzenną jednostką tworzenia, obróbki i dystrybucji produktów symboliczno-estetycznych (od sztuki po rozrywkę) oraz akumulowania kapitału w sektorach przemysłów kreatywnych i kulturowych (por. Scott 2000);

(b) z punktu widzenia praktyk konsumpcyjnych mieszkańców, realizowanych w miejskich przestrzeniach („scenach”) przy użyciu różnego rodzaju obiektów i walorów miejskich (tzw. amenities) (Clark 2003a), które służą artykulacji, afirmacji i legitymizacji współdzielonych społecznie wartości, tożsamości i stylów życia o różnym stopniu dystynktywności;

(c) z perspektywy miejskich polityk i rozwoju terytorialnego, w których zasoby kulturowe miasta obsadza się w roli czynnika „miastotwórczego" przyciągającego jednostki określonych kategorii (turystów, mieszkańców, inwestorów) i generującego prosperity; zasoby te traktuje się jako element tworzenia autonomicznie rozumianej ,jakości życia” (Błaszczyk, Pluta 2015; Klekotko i in. 2015, s. 13-28; Majer 2014) ${ }^{1}$.

Ambicje całościowego ujęcia nowego „reżimu” rozwoju miast opartego na kulturze i rozrywce mają — łączące wyżej przedstawione wątki — koncepcja miasta jako „maszyny rozrywki” Terry'ego N. Clarka (2003) i komplementarna wobec niej teoria klasy kreatywnej i miasta kreatywnego (Florida 2010; Landry 2013). Metafora miasta jako „maszyny rozrywki”

${ }^{1}$ W tym ostatnim nurcie można osadzić także te koncepcje kultury, które jej transformatywną rolę (źródło mechanizmów rozwojowych) widzą w rozwiązywaniu problemów społecznych, generowaniu kapitału społecznego i ludzkiego, integracji społecznej, mobilizacji wokół celów wspólnotowych i tworzenia nowych modeli współpracy, które pośrednio przełożą się na rozwój gospodarczy (por. Hausner, Karwińska, Purchla 2013; Pluta 2018). 
ma odzwierciedlać nową sytuację społeczną, w której masowa podaż dóbr rozrywki oraz klimat kulturalny miejsca stają się czynnikami rozwoju czynnikami „miastotwórczymi”. O ile miasto dawne („fordowskie”) było miastem przemysłowym i przestrzenną jednostką reprodukcji siły roboczej (głównie wielkomiejskiej klasy robotniczej) w systemie konsumpcji zbiorowej (Castells 1982), o tyle charakter współczesnych miast epoki postfordyzmu, postmodernizmu czy postindustrializmu wyznacza przewaga sektora usług, nowych technologii i przemysłów kulturowo-kreatywnych - typowych dla gospodarek opartych na wiedzy, w których dominującą siłą społeczną staje się „klasa kreatywna” (nowa klasa miejska), a czynnikiem miejskiego ożywienia szeroko rozumiana konsumpcja i rozrywka w jej zindywidualizowanej lub trybalnej, symboliczno-doznaniowej postaci. W pewnym sensie miasto postfordowskie również zakłada reprodukcję siły roboczej, jednakże dokonuje się ona nie w wyniku „fizycznej” regeneracji zdolności klasy robotniczej do wysiłku poprzez zapewnienie podstawowych dóbr i usług publicznych, lecz dzięki stwarzaniu bogatej oferty kulturalnej i „klimatu miejsca” jako ekosystemu życia dla klasy kreatywnej (Bartkowski 2016, s. 123). Kultura jest więc nie tylko bezpośrednim źródłem rozwoju (jako działalność przemysłowa i usługowa), ale także pośrednim źródłem zasileń (poprzez system udogodnień, atmosferę miejsca) klasy kreatywnej zatrudnionej w różnych sektorach gospodarki (Florida, Gates 2003):

„Z jednej strony chodzi zatem o zwabienie mieszkańców i turystów, którzy oddawaliby się w mieście konsumpcji i generowali tym samym wzrost gospodarczy, z drugiej o przyciągnięcie kapitału ludzkiego, owej creative class, która przez swoją zdolność innowacyjnego i kreatywnego myślenia przyczynia się do rozwoju ekonomii opartej na wiedzy" (Klekotko i in. 2015, s. 23).

W tej mierze, w jakiej konsumpcja staje się kluczowym czynnikiem rozwoju społeczno-ekonomicznego, zyskuje także centralne miejsce w systemie politycznym (w tym polityce lokalnej) (Clark 2003b). Obok tradycyjnych kwestii tworzenia otoczenia probiznesowego, nowych miejsc pracy czy rozwiązywania problemów socjalnych w agendzie działań władz można znaleźć aktywności nastawione na budowanie wizerunku miasta wśród rzeczywistych i potencjalnych mieszkańców, tworzenie identyfikacji z danym miejscem, dostarczanie udogodnień i kreowanie jakości życia. O jakości przestrzeni miasta i jego rozwoju decyduje przy tym także to, co dzieje się poza tradycyjnymi instytucjami kultury, jak kina, teatry czy centra kultury, a co wyrasta $z$ atmosfery przestrzeni publicznych, ulic, parków, życia nocnego, architektury itp. (Klekotko i in. 2015, s. 24; Florida 2010). 
Polityka rozwoju miasta jest polityką tworzenia udogodnień sprzyjających realizacji stylów życia i zaspokajaniu potrzeb różnych kategorii mieszkańców i przyjezdnych. Odbywa się to w znacznej mierze za pośrednictwem miejskiego systemu okazji, to jest zinstytucjonalizowanego kompleksu powiązanych wzajemnie form przestrzennych, instytucjonalnych i społecznych, służących udostępnianu zasobów i środków konsumpcji. W systemie tym mają miejsce akty przywłaszczania różnorakich dóbr, wrażeń, symboli i doświadczeń oraz dochodzi do kultywowania wspólnot, tożsamości, wyrażania stylu życia (Błaszczyk, Cebula 2016, s. 103). Przestrzenie o różnej ofercie praktyk konsumpcyjnych stanowią „sceny" kulturowe przyciągające zróżnicowane grupy uczestników-konsumentów, poszukujących odmiennych wrażeń i realizujących odmienne style życia. Scena jest w pewnym sensie przestrzenną reprezentacją wspólnoty kulturowej powstałej na bazie współdzielenia określonych znaczeń, emocji, wartości i motywów. Wyraziste sceny kulturowe mogą nadawać charakter całemu miastu, czynić go „marką” rozpoznawalną wśród mieszkańców i turystów, a tym samym stanowią jego „kapitał” i atraktor innych produktywnych zasobów (Klekotko i in. 2015, s. 20-23, 36-46).

Funkcjonowanie miast i regionów w reżimie „maszyny rozrywki” czy miasta kreatywnego nie byłoby możliwe bez ogólnych przekształceń społecznych. Miasto jako przestrzeń konsumpcji i przestrzeń konsumowana jest wytworem społeczeństwa i kultury konsumpcyjnej (Jayne 2006), które aktywnościom i rolom związanym $z$ konsumowaniem nadają nowy status i nowe funkcje. Konsumpcja $z$ jednej z wielu czynności życia codziennego przekształca się w kategorię organizującą ład społeczny, systemową reprodukcję, społeczną integrację i dyskursy jaźni (Bauman 2006; Iwasiński 2016). Odpowiada temu pojęcie ko n sumeryz mu, rozumianego nie jako czynność czasu wolnego, lecz całościowy „sposób życia” (Jayne 2006, s. 5). Jego ekspansja nie byłaby możliwa bez nadania konsumpcji nowych właściwości, z których kluczowe wydają się: zdolność do niemal nieograniczonej semiozy (uznakowienia), estetyzacja życia codziennego, doznaniowość, różnorodność i pluralizm oferty (Baudrillard 2006; Featherstone 2001).

\section{MIASTO JAKO POLE SPOŁECZNE - W STRONĘ KONCEPCJI PIERRE'A BOURDIEU}

Uznanie regeneratywnej i pobudzającej roli kultury miejskiej może stwarzać wrażenie, iż jej dobroczynny wpływ obejmuje wszystkich jego mieszkańców, co jest sprzeczne z obrazem miasta podzielonego i nierów- 
nego. Dający się zaobserwować dualizm w badaniach nad miastem rozbieżność między ujęciem uwrażliwionym kulturowo, które jednak nie pozwala wiele powiedzieć na temat nierówności społecznych, a ujęciem polityczno-ekonomicznym, które nie obejmuje bezpośrednim zainteresowaniem spraw kultury - każe zadać pytanie o perspektywy pogodzenia tych podejść (Hanquinet, Savage, Callier 2012; Savage i in. 2018). Syntezę taką może stanowić teoria Pierre'a Bourdieu, otwierająca drogę dla rekonceptualizacji miasta jako „dziedziny akumulacji, dyferencjacji i kontestacji różnych form kapitału, co czyni z miasta główny teren, produkt i wygraną walk historycznych" (Wacquant 2018, s. 90). Z tej perspektywy miasto jest obszarem ujawniania się i odtwarzania poprzez wzory konsumpcji i uczestnictwa w kulturze nierówności społecznych, hierarchii symbolicznych i stosunków dominacji (w tym tych o charakterze klasowym). Sharon Zukin (1998), w nawiązaniu do koncepcji Bourdieu (2005), dowodzi, że style życia stanowią dzisiaj wyraz agresywnej pogoni za kapitałem kulturowym, są więc środkiem akumulowania przewag i przywilejów społecznych. W związku z tym niektórzy badacze wskazują, że w obszarze miasta odbywa się rywalizacja i konkurencja między odmiennymi stylami $\dot{z} y c i a$ oraz że rezultatem tego konfliktu jest formowanie przestrzeni miasta (systemu okazji) w taki sposób, który faworyzuje grupy w nim dominujące: „klasę kreatywną”, „nowych mieszczan” (Błaszczyk 2015; Błaszczyk, Cebula 2016). Wyłaniający się miejski system okazji odwzorowuje aspiracje, potrzeby i oczekiwania mieszkańców, przede wszystkim tych, którzy dysponują największymi zasobami, a zatem także siłą polityczną (władzą). Jego kształt jest rezultatem skomplikowanej gry interesów i rywalizacji o dominację w przestrzeni.

Takie konfliktogenne ujęcie miasta znajduje rozwinięcie teoretyczne w koncepcji pola (champ) Bourdieu. Idea pola ucieleśnia relacyjny sposób myślenia o rzeczywistości, w którym określone właściwości agentów ich działania, interesy, poglądy oraz posiadane zasoby — nabierają znaczenia dopiero $w$ zestawieniu i wzajemnym odniesieniu do siebie ponieważ zachodzą między nimi relacje obiektywne (niezależnie od woli i świadomości) (Bourdieu, Wacquant 2001, s. 78; Bourdieu 1983, s. 312-313). Pole to względnie autonomiczna przestrzeń wzajemnie ukierunkowanych aktywności określonego rodzaju (jak pole naukowe, artystyczne, polityczne, ekonomiczne, religijne, klas społecznych), uspójniona podzielanymi (w zasadzie milcząco) „regułami gry” i „stawkami”, o jakie toczy się rywalizacja (np. prestiż akademicki, kapitał finansowy, autorytet religijny).

W płaszczyźnie synchronicznej pola są ustrukturyzowanymi przestrzeniami pozycji (stanowisk), których właściwości zależą od miejsca w tej 
przestrzeni i które mogą być analizowane niezależnie od osób je zajmujących (Bourdieu 1995, s. 72). Strukturę pola (a co za tym idzie, relacje władzy i możliwości działania) wyznacza dystrybucja określonych zasobów (właściwości), które gdy są aktywne w danym polu, stają się kapitałami. Kapitał czy rodzaj kapitału to coś, co jest efektywne w danym polu zarazem jako broń (atut, jak w grze karcianej) i jako stawka w walce, coś, co pozwala posiadaczowi sprawować władzę, wywierać wpływ i gromadzić "dochody" (Bourdieu 1985, s. 724; Bourdieu, Wacquant 2001, s. 79, 83).

W płaszczyźnie dynamicznej pola są przestrzeniami gry, w których jednostki angażują swoją energię i pracę (milcząco uznając jej reguły oraz to, że gra jest „warta świeczki” — tzw. illusio), inwestują zasoby (kapitał), własne zrozumienie gry, umiejętności i dyspozycje (habitus) w celu zdobycia określonych zysków. Istnienie pól zakłada istnienie specyficznych stawek, o które toczy się gra (odzwierciedlających wielość możliwych celów indywidualnych i społecznych), oraz ludzi przysposobionych do gry, to jest agentów wyposażonych w odpowiednie habitusy, złączonych wspólnym interesem, uznających zasadność gry, posiadających stosowne „przekonania", dyspozycje i umiejętności (będące także wytworem historii pola) (Bourdieu 1995, s. 72-73). Przedmiotem rywalizacji może być zarówno (a) akumulacja szczególnej dla danego pola formy kapitału (np. zysk pieniężny w polu gospodarczym czy kapitał kulturowy i autorytet w polu naukowym), jak i kontrola nad definiowaniem reguł gry (stosowanie przemocy symbolicznej) przez określenie: (b) względnej wagi (hierarchii, „kursów wymiany”) różnych form kapitału oraz (c) tego, jakie zasoby i kompetencje będą uznane za wartościowe w przyszłości (co będzie kapitałem). Chodzi więc o monopol w zakresie definiowania prawomocnej zasady dominacji (Swartz 2013, s. 59-60; Bourdieu, Wacquant 2001, s. 21, 80-81).

$\mathrm{Z}$ reguły specyfikę danego pola wyznacza przeważający $\mathrm{w}$ nim rodzaj kapitału (np. kulturowy w polu produkcji artystycznej czy ekonomiczny w polu gospodarczym). Analogicznie można dowodzić, iż tym, o co toczy się gra wśród mieszkańców miasta, jest swoisty „kapitał miejski” rozumiany jako waloryzowana przestrzeń fizyczna, czyli dobra i właściwości rozlokowane terytorialnie, mające charakter dóbr rzadkich (jak mieszkania i domy, dzielnice i obszary z dostępem do miejskiej infrastruktury: edukacyjnej, rekreacyjnej, transportowej itp., sąsiedztwa gwarantujące bezpieczeństwo i spokój oraz bliskość osób uznanych za „pożądane” itp.) (zob. Bourdieu 2018, s. 110-111). Członkowie różnych klas i frakcji klasowych, jako agenci społeczni, stosownie do posiadanych zasobów i umiejętności „przywłaszczają" (materialnie i symbolicznie) różne obszary miasta: na- 
bywając i wynajmując mieszkania czy opanowując (użytkowując) miejski system udogodnień. W rezultacie przestrzenie te nabierają emblematów ich stylu życia, co sprawia, że stają się nacechowane symbolicznie i jako takie są rozpoznawane przez innych, stanowiąc źródło identyfikacji lub odrzuceń, element tożsamości (Rosenlund 2017, s. 27-28). Jak dowodzi Bourdieu (2018, s. 108; por. Wacquant 2018), zawłaszczanie przestrzeni jest jednym ze sposobów sprawowania władzy i wywierania przemocy symbolicznej (tym skuteczniejszym, że odbywa się poprzez „naturalny” porządek rzeczy i miejsc). Fizyczna struktura miasta stanowi więc obszar rywalizacji różnych stylów życia, a także różnych wizji „miejskości” i „zamieszkiwania". Dominujący w polu są zdolni wytwarzać i wpajać takie schematy klasyfikacyjne, które porządkują, uświęcają bądź dyskredytują pewne grupy i lokalizacje, a przez to umacniają lub modyfikują porządek społeczny i jego materializacje (zob. Lewicki, Drozdowska 2017). Opanowanie przestrzeni sprzyja pomnażaniu już posiadanych zasobów, takich jak kapitał kulturowy (np. poprzez dostęp do instytucji i scen kulturowych), ekonomiczny (np. poprzez rynek nieruchomości) czy społeczny (poprzez możliwość utrzymywania relacji, w tym relacji z osobami zasobnymi w kapitały).

Możliwości i sposoby opanowywania przestrzeni miasta (w tym anektowania jego obszarów i instytucji w celu budowania stylów życia) są limitowane przez wielkość i kompozycję zgromadzonego kapitału: ekonomicznego (środki finansowe), kulturowego (kompetencje i zainteresowania) oraz społecznego (więzi i kręgi przynależności) ${ }^{2}$. W zależności od habitusu (dyspozycji), pozycji w polu (wyznaczonej wielkością zgromadzonych zasobów i względnym udziałem kapitału ekonomicznego i kulturowego), trajektorii (historii bycia w polu, pochodzenia - na przykład „zasiedziali” versus „nowo przybyli”) różne frakcje mieszkańców będą artykułowały odmienne interesy, stosowały inne strategie działania i poszukiwały innych nisz konsumpcyjnych. Zgodnie z przyjętym rozumieniem pola gra może się toczyć o kapitał już zdefiniowany (np. dostęp do miejskiej infrastruktury transportowej), a także o to, co będzie kapitałem i w jaki sposób będzie on „naliczany”. W tym ostatnim przypadku przedmiotem sporu może być na przykład to, w jakim stopniu przestrzeń miejska ma być dostępna na zasadzie uprawnień opartych na pieniądzu, a w jakim

\footnotetext{
2 Samo zajmowanie przestrzeni fizycznej nie prowadzi automatycznie do skorzystania $z$ szans, jakie ona oferuje. Niezbędne jest bowiem dysponowanie środkami przyswajania tych szans (np. w postaci kapitału kulturowego). To w tym sensie można mówić, iż „habitus wytwarza habitat" (Bourdieu 2018, s. 111).
} 
uwzględnia się uprawnienia innego rodzaju - potrzeby kulturalne, zasiedziałość (historię) ${ }^{3}$, sąsiedztwo, więzi społeczne itp. W walce o prestiż i uznanie poszczególne kategorie mieszkańców mogą także dążyć do redefinicji już istniejących stawek, czyli do narzucenia takiej definicji kapitału, która będzie waloryzować ich stan posiadania (np. mieszkańcy przedmieść mogą podnosić wartość ich przestrzeni zamieszkania, uruchamiając narracje i symbolikę odwołującą się do „ciszy”, „spokoju”, „wygody” w opozycji do „zgiełku”, „pośpiechu” i „ciasnoty” charakteryzujących centra wielkich miast).

Przekładając to na grunt miejskiego systemu konsumpcji, można założyć, że młodzi przedstawiciele „klasy kreatywnej” (relatywnie bogatej w kapitał kulturowy, społeczny i ekonomiczny) będą dążyć do utrzymania miejskiego systemu okazji w wersji ponowoczesnej, opartej na doznaniowej kulturze konsumpcyjnej, podczas gdy starsi (o innym systemie dyspozycji), ukierunkowani na więzi bliskiego typu, „wypychani” z miasta, będą poszukiwać alternatywnych obszarów uczestnictwa, nie zawłaszczonych przez indywidualistyczną i skomercjalizowaną kulturę (zob. Błaszczyk, Cebula 2016). Także osoby o rozbudowanych potrzebach kulturalnych (frakcja „intelektualna” klasy dominującej) enklaw dla swojego sposobu życia mogą poszukiwać na obrzeżach miejskiego systemu konsumpcji, poza sferą oficjalnych instytucji.

Ujęcie w kategoriach pola społecznego uwrażliwia badaczy na fakt, iż miasto i jego instytucje są pochodną złożonej i utajonej gry interesów, obejmującej nie tylko płaszczyznę materialnych zasobów, ale także symboliczne narracje i kody legitymizujące podział przestrzeni (Wacquant 2018, s. 99), w których są zawarte różne wizje „miejskości” i porządku społecznego (np. to, jakie praktyki i style życia mają mieć pierwszeństwo w mieście). W wyniku tej gry dochodzi do reprodukowania i modelowania fizycznej tkanki miasta (tutaj: miejskiego systemu konsumpcji). Kwestią sporną pozostaje to, $\mathrm{w}$ jakim stopniu pola miejskie są przestrzeniami gry o sumie zerowej (a w jakim można mówić o rywalizacji „równorzędnych”, względnie autonomicznych stylów życia) oraz w jakim stopniu wyznaczane granice symboliczne są granicami klas i frakcji klasowych (zob. Lewicki, Filiciak 2017, s. 14-20; Lewicki, Drozdowska 2017). Choć odpowiedzi na te pytania wymagają pogłębionych badań empirycznych, częściowo wy-

\footnotetext{
${ }^{3}$ Jedna z osi podziałów przebiega między mieszkańcami „zasiedziałymi” i „przyjezdnymi” („słoikami”). Podział ów wynika z narracji uruchamianej w walce o prestiż i uznanie podejmowanej przez grupy podobnych pod względem kompozycji kapitałów (przedstawicieli klasy średniej i wyższej) (zob. Lewicki, Drozdowska 2017).
} 
kraczających poza przedstawiony niżej materiał badawczy, to zakładam, że style życia mają charakter klasowy (co nie wyklucza zróżnicowań opartych na innych zmiennych) oraz że odzwierciedlają klasowe stosunki dominacji.

Zaprezentowana konceptualizacja miasta i miejskości pozwala przezwyciężyć ograniczenia przestrzenno-morfologicznego paradygmatu studiów miejskich i wyjść poza geograficzne i ekonomiczne analizy miejskiego życia, na nowo wprowadzając zagadnienie „miejskości” w aspekcie społecznym i kulturowym. Ujęcie miasta z perspektywy pola odpowiada postulatowi kulturalistycznych studiów miejskich, aby fenomen „miejskiej kultury" rozpatrywać jako względnie autonomiczny obszar funkcjonowania miasta, czyli przyjąć nieredukcjonistyczny i niedeterministyczny punkt widzenia (Klekotko i in. 2015). Jednocześnie zastosowanie koncepcji teoretycznych Bourdieu pozwala przywrócić zaniedbany wątek miejskich podziałów i nierówności o charakterze klasowym, coraz częściej obsadzany $\mathrm{w}$ roli głównego problemu $\mathrm{w}$ rozwoju miast i ukrytego problemu politycznego (zob. Florida, Adler 2017). Paradoksalnie, teoria klas Pierre'a Bourdieu może być adekwatna w czasach, w których klasy nie są ważnym komponentem subiektywnej tożsamości, politycznych dyskursów i politycznej mobilizacji (na co zwracali uwagę zwolennicy tezy o „śmierci klas"; por. Pakulski, Waters 1996; Clark, Lipset 2001). Klasowy charakter współczesnych społeczeństw określa bowiem nie świadomość własnego położenia, lecz przyjmowane za oczywiste sposoby postrzegania, myślenia i działania w świecie ugruntowane w klasowych habitusach (Cebula 2017; Flemmen, Jarness, Rosenlund 2017).

\section{PROBLEMATYKA BADAŃ I METODA}

Przyjmuję za Pierre'em Bourdieu, że zadaniem nauki jest rekonstrukcja obiektywnych warunków społecznych (systemu pozycji i relacji między nimi) i tego, jak za pośrednictwem systemów dyspozycji przenikają one do praktyki ludzkiej (Bourdieu, Wacquant 2001, s. 98), a za cel przedstawionej tu pracy uznaję pokazanie, w jaki sposób mieszkańcy miasta o określonych profilach społeczno-demograficznych, wyposażeni w odmienne habitusy i dysponujący zróżnicowanym repertuarem zasobów (ekonomicznych, kulturowych i społecznych), użytkują i opanowują miejskie przestrzenie konsumpcji - czyli realizują w nich określone style życia. Jest to jednocześnie pytanie o miejski system nierówności (nierówne „prawa do miasta") i symboliczną dominację klas. Zakłada się bowiem, że gdy rozwój miasta oparty jest na rozwoju konsumpcji i kultury, przestrzeń 
symboliczna (praktyk i gustów) wyraża i reprodukuje podziały społeczne, uczestniczy w procesie akumulowania i konwertowania kapitałów, utrzymywania dystansów i hierarchii społecznych. Pośrednio analiza praktyk mieszkańców pozwala określić kierunki polityki miejskiej, wskazując, jakie zachowania mieszkańców są przez miejski system okazji faworyzowane (zyskują w nim symboliczną supremację).

Bazę empiryczną ${ }^{4}$ analiz stanowią wywiady kwestionariuszowe $(\mathrm{N}=$ 300) przeprowadzone w 2016 roku na niereprezentatywnej próbie mieszkańców Wrocławia w wieku 18-67 lat, dobieranych celowo według kryterium zawodowego ${ }^{5}$. Celem projektu badawczego było rozpoznanie społecznych uwarunkowań i korelatów wzorów konsumpcji, czyli tego, jak wpisują się one w zróżnicowania i podziały społeczne oraz łączą z parametrami sieci jednostek. Przedmiot analiz stanowią praktyki uczestnictwa w kulturze i czynności czasu wolnego mieszkańców W., zarówno typowo miejskie, jak „chodzenie do kina” czy „spacerowanie po sklepach, galeriach handlowych”, jak i niemiejskie w rodzaju „wyjeżdżania za miasto, na wycieczki”, „zwiedzania zabytków, zamków” ${ }^{6}$. Praktyki te, poddane analizom wielowymiarowym (ukazującym powinowactwa stylu), zostały skonfrontowane ze zmiennymi demograficznymi i strukturalnymi (klasowymi). Te ostatnie operacjonalizowano zarówno poprzez rodzaj wykonywanego zawodu, stanowiący ugruntowany w studiach nad stratyfikacją wskaźnik społecznego usytuowania (Domański 2007), jak i poprzez dystrybucję różnych form kapitału (Bourdieu 2005). Istotną osią analiz, nieobecną w rekonstrukcji przestrzeni społecznej dokonanej przez Bourdieu,

\footnotetext{
${ }^{4}$ Projekt badawczy nr 0420/1814/16, finansowany ze środków grantowych Wydziału Nauk Społecznych Uniwersytetu Wrocławskiego.

${ }^{5}$ Rekrutowano po 100 osób z trzech szerokich kategorii zawodowych (oznaczonych jako A, B i C), skonstruowanych na bazie Społecznej Klasyfikacji Zawodów (Domański, Sawiński, Słomczyński 2007). Kategorie te stanowią miernik klas społecznych. Kategorię A tworzyły: wyższe kadry kierownicze, menadżerowie, prywatni przedsiębiorcy (zatrudniający co najmniej 5 osób) oraz specjaliści. Kategoria B składała się z: techników, pracowników administracyjnych i specjalistów średniego szczebla, pracowników biurowych, drobnych przedsiębiorców (zatrudniających od 1 do 4 osób), osób samozatrudniających się i wykwalifikowanych pracowników handlu i usług. Kategorię C tworzyli: robotnicy, sprzedawcy i szeregowi pracownicy usług, niewykwalifikowani pracownicy usług.

${ }^{6} \mathrm{~W}$ sumie uwzględniono 23 praktyki, reprezentujące różne poziomy kulturowej „prawomocności” i „instytucjonalizacji” (por. Szlendak, Goszczyński, Krajewska 2019) (począwszy od kultury wysokiej, jak teatr i opera, a skończywszy na aktywnościach dnia codziennego, jak uprawianie ogródka, działki). „Uczestnictwo w kulturze” nie jest tu także redukowane do biernego odbioru treści ani zachowań rynkowych, lecz ma spełniać kryteria aktywnego współtworzenia tego, co konsumowane (zgodnie z ponowoczesnym rozumieniem konsumpcji) (Jayne 2006).
} 
jest wymiar kapitału społecznego (lub powiązań sieciowych), traktowany jako istotny korelat (czynnik warunkujący i warunkowany) aktywności kulturowo-konsumpcyjnej ${ }^{7}$. Przyjęta hipoteza mówi, że strategie opanowywania przestrzeni miejskich i manifestowania praktyk stylów życia są zarówno efektem sieciowego zakorzenienia (dostępności kontaktów i zasobów innych), jak i czynnikiem współtworzącym relacje i tożsamości grupowe (ośrodkiem więziotwórczym) (Lizardo 2006; Puetz 2015).

Koncepcja kapitału społecznego pozostaje w silnej zależności z koncepcjami sieciowymi (Lin 2001). Jej istotą jest uznanie, iż aktorzy społeczni (indywidualni i zbiorowi) mogą osiągać określone korzyści, realizować pewne cele lub zyskiwać zasoby z tytułu powiązań społecznych, uczestnictwa w strukturach społecznych i przynależności grupowej. Jak zwięźle wyraził to Ronald S. Burt (2001) — lepiej połączeni ludzie cieszą się większymi zyskami, przy czym przedmiotem teoretycznych sporów pozostaje to, co oznacza „bycie lepiej połączonym” (np. gęste sieci czy sieci z „dziurami strukturalnymi")?

Użytecznym elementem analizy będzie charakterystyka mieszkańców miasta („graczy” miejskiego pola konsumpcji) pod kątem ich ulokowania w sieciach społecznych. Chodzi o wskazanie, jakie formy więzi i w jakich konfiguracjach sprzyjają jakim typom uczestnictwa w miejskich i niemiejskich przestrzeniach konsumpcji lub jakie style konsumowania są funkcjonalne wobec jakich rodzajów powiązań sieciowych? Założyłem przy tym, że wzory konsumpcji i praktyk pozostają w relacji homologicznej do wzorów relacji międzyjednostkowych, a wykluczeniu z kultury miejskiej towarzyszy deficyt więzi społecznych określonego rodzaju.

\section{MIEJSKIE POLE PRAKTYK I STYLÓW ŻYCIA I ICH STRUKTURALNE PODŁOŻE}

W celu opisania zróżnicowań przestrzeni symbolicznej pola miejskiego analizie poddano 23 aktywności kulturalno-konsumpcyjne i czasu wolnego. Tabela 1 zawiera wyodrębnione $\mathrm{w}$ wyniku analizy głównych składo-

\footnotetext{
7 Przedstawione ujęcie klas różni się od kategorialnego ujęcia Richarda Floridy (2010) tym, iż uznaje się wielowymiarowy charakter zróżnicowań (nieredukowalnych do zróżnicowań ekonomicznych i charakteru pracy) (zob. Cebula 2017). Jednocześnie można argumentować, iż tzw. klasa kreatywna Floridy daje się zinterpretować, w duchu teorii Bourdieu (2005), jako klasa kumulująca nowy typ kapitału kulturowego (opartego na kreatywności i swobodnym stylu bycia) (jak „nowa burżuazja” czy „nowe drobnomieszczaństwo”) w opozycji do starszych i bardziej tradycjonalistycznych odłamów klasy wyższej i średniej.
} 
wych $^{8}$ style konsumpcji mieszkańców miasta, wraz z budującymi je praktykami ${ }^{9}$.

Pierwszy styl, określony jako kulturalny, kumulował te czynności, które zwykło się określać jako uczestnictwo w kulturze wysokiej (identyfikowanej przez takie obiekty, jak opera, teatr czy muzea i galerie). W jego skład weszły także amatorska twórczość artystyczna oraz noszące znamiona luksusu korzystanie $z$ "zabiegów upiększających, SPA, odnowy biologicznej, sauny, solarium, masażu itp." Styl ten w najwyższym stopniu łączył się z podziałem klasowym (eta $=0,229$ ), będąc bliskim kategorii „kadry kierownicze, menadżerowie, przedsiębiorcy i specjaliści z wyższym wykształceniem" (kategoria A w schemacie), a zupełnie odległym dla reprezentantów kategorii C. Dystynktywny charakter tego sposobu „uczestnictwa $\mathrm{w}$ mieście” potwierdzała pozytywna korelacja $\mathrm{z}$ wykształceniem $\left(r^{10}=0,215 ; p<0,001\right)$, kapitałem rodzinnym (tj. liniową kombinacją wykształcenia rodziców) $(r=0,257 ; p<0,001)$, sytuacją finansową gospodarstwa ${ }^{11}(r=0,204 ; p<0,001)$ czy subiektywnie postrzeganym statusem $^{12}(r=0,292 ; p<0,001)$. Można więc uznać, iż styl ten stanowi element tożsamości szeroko rozumianej elity.

Drugi z wyodrębnionych stylów - nazwany gastronomicznorozrywkowym - skupiał te czynności i przestrzenie konsumpcji, które cechowała niższa prawomocność jako raczej synonim kultury „ulicznej” czy popularnej, jak modne ,jadanie w foodtruckach”, chodzenie do restauracji, kawiarni i pubów, chodzenie na imprezy do klubów i dyskotek czy korzystanie z obiektów sportowych typu baseny, siłownie, kluby fitness. Specyfika tych aktywności nasuwa przypuszczenie, że są one domeną młodszych pokoleń, bardziej zorientowanych na zabawowy wymiar

${ }^{8}$ Miara adekwatności doboru próby KMO wyniosła 0,882, test sferyczności Bartletta był istotny statystycznie. Przyjęto rozwiązanie z sześcioma czynnikami wyjaśniającymi łącznie $66,27 \%$ wariancji pierwotnego zbioru danych. Pierwszy czynnik wyjaśniał $21,4 \%$ wariancji (po rotacji), $2-13,4 \%, 3-10,8 \%, 4-7,7 \%, 5-6,9 \%, 6-6,1 \%$. Do opisania czynników użyto rotacji Varimax.

9 Poszczególne czynności ( $z$ wyjątkiem oglądania telewizji) mierzone były na tej samej skali częstotliwości, gdzie wartość 1 oznaczała „nigdy”, 2 - „rzadziej niż raz na rok”, 3 „1-2 razy w roku”, 4 - „kilka razy w roku”, 5 — „co najmniej raz w miesiącu”.

10 Współczynnik korelacji Pearsona.

${ }^{11}$ Sytuację finansową gospodarstwa mierzono na pięciopunktowej skali, gdzie 1 — oznaczało „Żyjemy bardzo biednie, nie starcza nam nawet na podstawowe potrzeby” a 5 „Żyjemy bardzo dobrze — możemy sobie pozwolić na pewien luksus”.

12 Miarą statusu była odpowiedź na pytanie: „W Polsce są ludzie, którym powodzi się lepiej i gorzej. Proszę zaznaczyć, gdzie umieścił(a)by Pan(i) siebie na skali od 1 do 10, gdzie 1 to ci którzy mają najgorzej, a 10 to ci którzy mają najlepiej?”. 
Praktyki miejskiego pola konsumpcji — analiza głównych składowych

\begin{tabular}{|c|c|c|c|c|c|}
\hline \multicolumn{6}{|c|}{ Style konsumpcji i uczestnictwa w kulturze } \\
\hline kulturalny & $\begin{array}{l}\text { gastrono- } \\
\text { miczno-roz- } \\
\text { rywkowy }\end{array}$ & turystyczny & rekreacyjny & wspólnotowy & masowy \\
\hline $\begin{array}{l}\text { 1. Opera, fil- } \\
\text { harmonia, } \\
\text { koncert } \\
\text { muzyki po- } \\
\text { ważnej }\end{array}$ & $\begin{array}{l}\text { 1. Jadanie } \\
\text { w food- } \\
\text { truckach }\end{array}$ & $\begin{array}{l}\text { 1. Chodzenie } \\
\text { po górach, } \\
\text { wędrowa- } \\
\text { nie }\end{array}$ & $\begin{array}{l}\text { 1. Spacery po } \\
\text { sklepach, } \\
\text { galeriach } \\
\text { handlo- } \\
\text { wych }\end{array}$ & $\begin{array}{l}\text { 1. Nabo- } \\
\text { żeństwa, } \\
\text { chodzenie } \\
\text { do kościoła }\end{array}$ & $\begin{array}{l}\text { 1. Imprezy } \\
\text { masowe } \\
\text { typu festy- } \\
\text { ny, targi, } \\
\text { festiwale }\end{array}$ \\
\hline $\begin{array}{l}\text { 2. Muzea, } \\
\text { wystawy, } \\
\text { galerie... }\end{array}$ & $\begin{array}{l}\text { 2. Restau- } \\
\text { racja, } \\
\text { kawiarnia, } \\
\text { pub }\end{array}$ & $\begin{array}{l}\text { 2. Wycieczki } \\
\text { za miasto }\end{array}$ & $\begin{array}{l}\text { 2. Spacery po } \\
\text { parku }\end{array}$ & $\begin{array}{r}\text { 2. Działka, } \\
\text { ogródek }\end{array}$ & $\begin{array}{l}\text { 2. Wyda- } \\
\text { rzenia } \\
\text { sporto- } \\
\text { we, mecze, } \\
\text { zawody }\end{array}$ \\
\hline 3. Teatr & $\begin{array}{l}\text { 3. Klub, dys- } \\
\text { koteka }\end{array}$ & $\begin{array}{l}\text { 3. Zamki, } \\
\text { zabytki }\end{array}$ & & $\begin{array}{l}\text { 3. Nie oglą- } \\
\text { da filmów, } \\
\text { seriali na } \\
\text { DVD lub } \\
\text { kompute- } \\
\text { rze }\end{array}$ & 3. Telewizja \\
\hline $\begin{array}{l}\text { 4. Koncer- } \\
\text { ty muzyki } \\
\text { rozrywko- } \\
\text { wej }\end{array}$ & $\begin{array}{l}\text { 4. Obiekty } \\
\text { sportowe: } \\
\text { baseny, } \\
\text { siłownie, } \\
\text { kluby fit- } \\
\text { ness }\end{array}$ & & & $\begin{array}{l}\text { 4. Nie chodzi } \\
\text { do kina }\end{array}$ & \\
\hline $\begin{array}{l}\text { 5. Bibliote- } \\
\mathrm{ki} / \text { media- } \\
\text { teki }\end{array}$ & 5. Kino & & & & \\
\hline $\begin{array}{l}\text { 6. Amatorska } \\
\text { twórczość } \\
\text { artystyczna }\end{array}$ & $\begin{array}{l}\text { 6. Filmy, se- } \\
\text { riale na } \\
\text { DVD lub } \\
\text { kompute- } \\
\text { rze }\end{array}$ & & & & \\
\hline $\begin{array}{l}\text { 7. Zabiegi } \\
\text { upiększa- } \\
\text { jące, SPA, } \\
\text { odnowa } \\
\text { biologiczna }\end{array}$ & & & & & \\
\hline 8. Kino & & & & & \\
\hline
\end{tabular}

Źródło: opracowanie własne na podstawie badań mieszkańców Wrocławia. 
miejskich scen i budowanie relacji z rówieśnikami ${ }^{13}$. Potwierdza to wysoki ujemny współczynnik korelacji z wiekiem $(r=-0,408 ; p<0,001)$. Im starsi byli badani, tym rzadziej realizowali ten styl konsumowania.

Inną zależność odnotowano $\mathrm{w}$ przypadku stylu kulturalnego, który choć był typowy dla osób młodych, to bardziej dotyczył dojrzałej frakcji (31-35 lat) niż najniższej kategorii wiekowej (18-25 lat) i najstarszych w próbie (48 lat lub więcej). Ci ostatni relatywnie częściej preferowali styl wspólnotowy (korelacja $z$ wiekiem: $r=0,241 ; p<0,001$ ), mający wszelkie znamiona stylu „ucieczkowego" czy też alternatywy dla miejskiego systemu okazji (w wersji kultury „elitarnej” lub „popularno-rozrywkowej”). Ten sposób partycypacji zamykał się w obszarach takich praktyk, jak „nabożeństwa, chodzenie do kościoła” i „jeżdżenie na działkę, uprawianie ogródka”, w dystansie wobec „chodzenia do kina” i oglądania filmów, seriali na DVD lub komputerze (a więc czynności definiujących typ gastronomiczno-rozrywkowy). Przypominał typ kultury konsumpcyjnej, który Terry N. Clark (2003b) określił jako „moralistyczny” (z jego naciskiem na etykę pracy, powściągliwość w spożyciu, antyhedonizm). W rekonstruowanej przestrzeni stylów życia w mieście styl ten zajmuje pozycję zdominowaną i jest oznaką społecznego wykluczenia (głównie osób starszych o mniejszych kapitałach) ${ }^{14}$.

Podobnie alternatywny wobec przeważającego systemu konsumpcji jest styl turystyczny, czyli takie aktywności „niemiejskie”, jak „chodzenie po górach”, „wycieczki za miasto”, czy zwiedzanie „zamków, zabytków”. Jednakże w odróżnieniu od stylu wspólnotowego łączy się on pozytywnie (choć jest to związek niezbyt silny) z cechami statusowymi: sytuacją finansową $\mathrm{w}$ gospodarstwie $(r=0,199 ; p<0,001)$ czy pozycją klasową (przynależność do kategorii A; eta $=0,165$ ). Może to świadczyć o tym, że część mieszkańców miasta - o większych niż przeciętne zasobach - poszukuje innych niż konsumpcyjny sposobów wykorzystania czasu wolnego, przekładając kontakt z przyrodą i odpoczynek nad miejski gwar, jednak nie bez ambicji edukacyjnych i poznawczych (vide „zwiedzanie").

Wśród mieszkańców miasta można znaleźć także przedstawicieli stylu ma s ow e go (zwłaszcza wśród robotników, w odróżnieniu od właścicieli przedsiębiorstw), którzy znajdują upodobanie w sferze kultury dużych imprez, masowego uczestnictwa (typu zawody sportowe, festyny, targi itp.)

13 Podobny styl, nazwany „orientacja na rozrywkę”, stwierdzono w badaniach Wrocławskiej Diagnozy Społecznej (Błaszczyk 2017).

${ }^{14}$ Występowanie tego stylu potwierdzają także inne badania (por. Błaszczyk 2017, s. 106). 
i rozrywki telewizyjnej, o niedyskryminacyjnym i nieelitarystycznym charakterze ${ }^{15}$, stwarzających możliwości zatopienia się we wspólnocie i afirmowania grupowych (czy też plemiennych) tożsamości.

Najmniej wyróżniał się (pod względem zmiennych strukturalnych) styl rekreacyjny, obejmujący praktyki przechadzania się po sklepach, galeriach handlowych oraz po parkach. Można go powiązać ze współczesną wersją miejskiego flâneur'a, odbiorcy konsumpcyjnych feerii, symulowanych światów obfitości i miejskiego zgiełku.

Wyodrębnione wzory czasu wolnego i praktyk legły u podstaw analizy segmentacyjnej mieszkańców $\mathrm{W}^{16}$. Zawarte $\mathrm{w}$ tabeli 2 wartości liczbowe informują o tym, w jakim stopniu dany styl konsumowania odchyla się od wartości przeciętnej dla całej próby, definiując (pozytywnie lub negatywnie) styl życia określonego segmentu.

Tabela 2

Miejscy konsumenci (wyniki analizy skupień metodą k-średnich*)

\begin{tabular}{|l|c|c|c|c|}
\hline \multirow{2}{*}{ Style konsumpcji } & \multicolumn{4}{c|}{ Typy konsumentów } \\
\cline { 2 - 5 } & wycofani & kulturalni & spacerowicze & gastroentuzjaści \\
\hline 1. Styl kulturalny & $-0,750$ & 0,878 & 0,219 & $-0,934$ \\
2. Styl gastronomiczno-rozrywkowy & $-1,209$ & 0,116 & $-0,168$ & 0,715 \\
3. Styl turystyczny & $-0,983$ & 0,104 & 0,340 & 0,296 \\
4. Styl rekreacyjny & 0,017 & $-0,428$ & 0,637 & 0,262 \\
5. Styl wspólnotowy & 0,463 & 0,303 & $-1,153$ & $-0,097$ \\
6. Styl masowy & $-0,022$ & 0,236 & $-1,188$ & 0,339 \\
\hline N (\%) & $53(17,7 \%)$ & $120(40 \%)$ & $46(15,3 \%)$ & $81(27 \%)$ \\
\hline
\end{tabular}

* Rozwiązanie uzyskane po 20 iteracjach.

Źródło: opracowanie własne na podstawie badań mieszkańców Wrocławia.

Można zauważyć, że konsumenci wycofani $(17,7 \%)$ uzyskują wartości wyraźnie poniżej średnich na wymiarach stylu: kulturalnego, gastronomiczno-rozrywkowego oraz turystycznego, wartości wysokie zaś osiągają dla stylu wspólnotowego. Pozostałe typy orientacji konsumpcyjnych

\footnotetext{
15 Uczestnictwo w tego typu wydarzeniach nie wymaga zasobów kapitału kulturowego. Odnotowano negatywną korelację tego stylu z wielkością kapitału rodzinnego $(r=-0,192$; $p<0,001)$.

${ }_{16}$ Podobne segmentacje przeprowadzali także inni badacze: w odniesieniu do małych i średnich miast (por. Szlendak, Goszczyński, Krajewska 2019) oraz miast dużych (metropolii), jak Warszawa (Kotnarowski i in. 2018) czy Wrocław (Błaszczyk 2017).
} 
pozostają $\mathrm{w}$ granicach wartości przeciętnych. Ten segment mieszkańców sytuuje się na obrzeżach lub poza głównym nurtem miejskiego systemu okazji w jego wersji (ponowoczesnej) „maszyny rozrywki” czy tradycyjnych przybytków kultury (jak teatr, opera czy kino) ${ }^{17}$. W odróżnieniu od nich kulturalni wydają się najczęstszymi odbiorcami kultury instytucjonalnej. Co ciekawe, nie jest im jednak zupełnie obcy styl wspólnotowy, co może wskazywać, że miasto i jego atrakcje nie zapewniają wystarczających środków zaspokojenia potrzeb i stąd poszukiwanie enklaw stylu życia w przestrzeniach quasi-publicznych (jak ogródki działkowe i kościoły). Odmienny profil reprezentują spacerowicze, amatorzy przechadzek po świątyniach konsumpcji (ale także po miejskich parkach) oraz wypadów za miasto (wycieczki, wędrówki po górach). Łączą w swoich praktykach miejski styl konsumowania z niemiejskim, przy czym nie można ich zaliczyć do grona „wykluczonych”. Ich selektywny stosunek do miejskiego systemu okazji (np. unikanie korzystania $z$ ich umasowionej i kolektywnej wersji), w połączeniu $z$ niewielkim, choć ponadprzeciętnym uczestnictwem w wymiarze „kulturalnym”, może wskazywać na pewne aspiracje do wzoru „człowieka kulturalnego” (realizowanego jednak w duchu indywidualizmu). Odrębny segment stanowią gastroentuzjaści, miłośnicy nowej kultury ulicznej (reprezentowanej przez foodtrucki), miejskich scen rozrywki i życia nocnego (klubów, dyskotek, barów itp.). Od „kulturalnych" odróżnia ich partycypacja w innego typu udogodnieniach (odległych od tradycyjnych i nieco nobliwych instytucji, jak muzea, teatry czy filharmonia). Są oni także relatywnie najintensywniejszymi konsumentami rozrywki masowej (dużych imprez, typu festiwale, festyny, zawody sportowe), nastawionymi na budowanie krótkotrwałych wspólnot i więzi o charakterze stycznościowym. Po spacerowiczach stanowią drugi segment zaangażowanych $\mathrm{w}$ eskapady za miasto i przechadzanie się po miejskich przestrzeniach konsumpcji.

17 Obecność mniej aktywnych konsumentów miejskiego systemu okazji stwierdzono we wszystkich przywoływanych analizach. Różny zakres ich występowania można tłumaczyć nie tylko odmiennością zastosowanych wskaźników konsumpcji kulturalnej (im rzadsza praktyka, tym większy udział „kulturowo pasywnych”), ale prawdopodobnie także wielkością miejscowości i różnorodnością pola oferty kulturalnej. Na przykład w małych i średnich miastach (Szlendak, Goszczyński, Krajewska 2019) udział kulturowo pasywnych (ograniczających swoją aktywność kulturalną głównie do telewizji) wyniósł 67\%, a Warszawie „tradycyjni nieuczestnicy" stanowili $22 \%$ populacji (por. Kotnarowski i in. 2018). W obu przypadkach jednak, podobnie jak w omawianych badaniach (patrz niżej), przynależność do tych segmentów rosła wraz z wiekiem i niższym kapitałem kulturowym. 
Charakterystyka demograficzna i społeczno-ekonomiczna wyodrębnionych typów mieszkańców skłania do wniosku, iż realizowany styl życia pozostaje $\mathrm{w}$ istotnym i nieprzypadkowym związku $\mathrm{z}$ usytuowaniem społecznym, w tym z dostępem do różnego typu kapitałów. Dość wspomnieć, iż wymiar wieku wyraźnie odróżniał segment „wycofanych”, ze średnią wieku wynoszącą 48,2 lata (mediana $=53$ ), od pozostałych segmentów, a zwłaszcza od "gastroentuzjastów” ( $\mathrm{M}=35$ lat; $\mathrm{Me}=34)$. Niewykluczone, iż zaobserwowane różnice $\mathrm{w}$ praktykach odzwierciedlają tzw. efekt kohortowy - przemiany pokoleniowe wynikające $z$ odrębności warunków nabywania habitusu (kształtowania systemu potrzeb). Młodsze pokolenia mieszczan, wychowanych w kulturze rynkowej obfitości, są lepiej przystosowane do miejskiego (ponowoczesnego) systemu okazji (w jego warstwie komercyjnej, rozrywkowej i doznaniowej) niż pamiętający czasy gospodarki niedoboru ${ }^{18}$. Nie bez znaczenia jest także sytuacja rodzinna. Otóż młodsi przeważnie są mniej obciążeni obowiązkami związanymi $\mathrm{z}$ wychowaniem dzieci (wśród gastroentuzjastów 50,6\% ma potomstwo, podczas gdy wśród „wycofanych” $\left.77,4 \%{ }^{19}\right)$.

Niezbędnym etapem analizy pola jest opisanie obiektywnej struktury pozycji, tj. przestrzeni sił (kapitałów) wyznaczających możliwe strategie gry i szanse jej zdominowania. Przestrzeń pozycji przekłada się na przestrzeń zajmowanych pozycji (tj. stylów życia) dzięki pośrednictwu przestrzeni dyspozycji (habitusów). Inaczej mówiąc, systematycznym odchyleniom w sferze praktyk i stosunków apropriacji przestrzeni miejskich powinny odpowiadać systematyczne odchylenia i różnice w kapitałach definiujących przestrzeń klas (Bourdieu, Wacquant 2001, s. 87-88). W celu sprawdzenia tej hipotezy w tabeli 3 zestawiono segmentację wrocławian ze względu na realizowane aktywności kulturalne z segmentacją klasową, rekonstruowaną na bazie zawodów.

Widać wyraźnie, iż prawdopodobieństwo przynależności do niektórych typów uczestnictwa $\mathrm{w}$ mieście określa pozycja $\mathrm{w}$ układzie stosunków klasowych ${ }^{20}$. Na przykład w klasie C jest relatywnie najwięcej osób zaliczonych do kategorii „wycofanych” (31\%), podczas gdy w segmencie A $47 \%$ badanych klasyfikuje się jako „kulturalnych” (wobec 30\%

\footnotetext{
18 Alternatywna hipoteza wskazywałaby na efekt dojrzewania, tj. różnice w stylu życia wynikające $z$ fazy cyklu życia.

${ }^{19} \mathrm{~W}$ tym segmencie relatywnie najwięcej jest także osób, które nie mieszkają już razem z dziećmi $(28,3 \%)$ - tzw. puste gniazda.

20 Ta zależność utrzymuje się także przy kontroli zmiennej „wiek” w modelu wielomianowej regresji logistycznej.
} 
Przynależność klasowa a typy konsumentów (procenty w kolumnach)

\begin{tabular}{|l|c|c|c|c|}
\hline \multirow{2}{*}{\multicolumn{1}{|c|}{ Typy konsumentów }} & \multicolumn{3}{c|}{ Kategoria „klasowa” } & \multirow{2}{*}{ Ogółem } \\
\cline { 2 - 4 } & klasa A & klasa B & klasa C & \\
\hline Wycofani & 8 & 14 & 31 & 17,7 \\
Kulturalni & 47 & 43 & 30 & 40 \\
Spacerowicze & 18 & 19 & 9 & 15,3 \\
Gastroentuzjaści & 27 & 24 & 30 & 27 \\
\hline Liczebność - N (100\%) & 100 & 100 & 100 & 300 \\
\hline
\end{tabular}

$\operatorname{Chi}^{2}(6, \mathrm{~N}=300)=24,686 ; p<0,001 ; V$-Cramera $=0,203$

Źródło: opracowanie własne na podstawie badań mieszkańców Wrocławia.

w klasie C). Bycie „spacerowiczem” jest uwarunkowane w równej mierze przynależnością do kategorii A i B, w odróżnieniu od C. Przykład "gastroentuzajstów” pokazuje natomiast, że pozycja klasowa nie zawsze łączy się ze sposobem konsumowania. Przypuszczalnie styl ten odzwierciedla inny wymiar społecznego zróżnicowania - wiek ${ }^{21}$. Jeśli uzna się, że pozycja zawodowa stanowi syntetyczny miernik udziału w strukturze dystrybucji kapitału (w tym ekonomicznego i kulturowego), to można wykazać, iż osoby pozbawione udziału w zasobach pozostają na marginesie miejskiego systemu konsumpcji, podczas gdy dysponujący nimi zajmują pozycję dominującą (tj. intensywnie korzystają $z$ oferty miasta).

Potwierdza to dalsza analiza stratyfikacyjna. „Wycofani” wyraźnie lokowali się na najniższych pozycjach $z$ uwagi na wszystkie wymiary społecznej strukturalizacji, to jest $\mathrm{w}$ wymiarze subiektywnego statusu (eta $\left.=0,319^{22}\right)$, kapitału kulturowego mierzonego wykształceniem $($ et $a=0,242)$, kapitału rodzinnego $($ eta $=0,373)$ i ekonomicznego ${ }^{23}$ $(e t a=0,345)$. W przeciwieństwie do nich "kulturalni” i „spacerowicze” wyróżniali się ponadprzeciętnym dostępem do kapitału, choć w ich przypadku dały się zaobserwować zaskakujące różnice. Otóż, wbrew intuicji

\footnotetext{
${ }^{21}$ Nie można wykluczyć, iż grupa „gastroentuzjastów” rozdziela się również według kryterium klasowego, jednak zastosowany zestaw wskaźników uniemożliwia uchwycenie tych różnic.

22 Współczynnik eta mierzy tutaj siłę związku między przynależnością do segmentu miejskich konsumentów a danym wymiarem stratyfikacji.

${ }^{23}$ Kapitał ekonomiczny mierzono poprzez sytuację finansową gospodarstwa (zob. przypis 11).
} 
(i ustaleniom przedstawionym przez Bourdieu w Dystynkcji) segment „kulturalnych" osiągał najwyższe wskazania, jeśli chodzi o sytuację finansową i subiektywnie pojmowany status, podczas gdy „spacerowicze” przodowali w zakresie kapitału kulturowego (wykształcenie) — zarówno własnego, jak i dziedziczonego (tj. rodziców). Trudno rozstrzygnąć, czy uzyskany rezultat jest anomalią wynikającą z niereprezentatywnego doboru próby (lub zastosowanych wskaźników), czy też mamy do czynienia z odwróceniem strategii zajmowania pozycji - frakcja „ekonomiczna” stara się dokonać rekonwersji kapitału ekonomicznego na kulturowy, a frakcja „intelektualna" ogranicza swoją konsumpcję w obszarze tradycyjnej kultury wysokiej (poszukując mniej oczywistych oznak dystynkcji) ${ }^{24}$.

\section{UCZESTNICTWO W MIEŚCIE A KAPITAŁ I SIECI SPOŁECZNE}

Teoria Pierre'a Bourdieu pozostaje istotną kanwą rozważań o miejskich przestrzeniach konsumpcji i zróżnicowaniu sposobów życia. Jednak jej praktyczne zastosowanie ograniczało się głównie do odnajdywania homologii między sferą stosunków klasowych lub statusu a sferą „zajmowania stanowisk" (tj. gustów, praktyk i posiadanych dóbr), przy czym zagadnienie więzi społecznych pozostawało na marginesie. Koncepcja kapitału społecznego stanowi ważny komponent teorii nierówności i reprodukcji społecznej (Bourdieu 1997), jednak w zasadzie pozostaje nieobecna w pracach empirycznych poświęconych rekonstruowaniu przestrzeni społecznej i odpowiadającej jej przestrzeni symbolicznej (stylów życia) (zob. Bourdieu 2005). Definiowaniu zróżnicowań społecznych służą przede wszystkim kapitał ekonomiczny i kulturowy (uznane za dominujące we współczesnych społeczeństwach kapitalistycznych). Tym samym związek kapitału społecznego $z$ wzorami konsumpcji (i kapitałem kulturowym) jest słabiej rozpoznany (zob. Erickson 1996; Warde, Tampubolon 2002; Kane 2004; Lizardo 2006; Cvetičanin, Popescu 2011). Ponieważ celem tych rozważań jest wzbogacenie analizy miejskiego pola o komponent sieci i powiązań, należy wziąć pod uwagę relacje łączącą różne wymiary kapitału społecznego ze zidentyfikowanymi typami miejskich konsumentów kultury.

\footnotetext{
${ }^{24}$ Warto dodać, iż różnice między „spacerowiczami” a „kulturalnymi” pod względem wielkości posiadanego kapitału nie były duże. Ponadto jeśli chodzi o zamożność gospodarstwa (tj. zasób posiadanych dóbr trwałego użytku), to „spacerowicze” lokowali się wyżej w hierarchii niż „kulturalni”.
} 
Pomocne w tym względzie jest scharakteryzowanie sieci społecznych wrocławian za pomocą takich parametrów, jak: wielkości sieci (network size), ich gęstość (density) i zróżnicowanie (heterogeneity) (Lewis i in. 2008, s. 334). Pierwszy z nich odnosi się do liczby partnerów (tzw. alters), z którymi jednostka utrzymuje określone relacje. Może być interpretowany jako miara integracji społecznej, statusu lub ogólnej aktywności. „Słabe połączenia” (weak ties), zgodnie z teorią Marka Granovettera (1973), zapewniają dostęp do nieredundantnych źródeł informacji, pełniąc funkcję „społecznych pomostów” o charakterze integracyjnym. „Więzi silne” (strong ties) mogą stanowić źródło społecznego i emocjonalnego wsparcia. Gęstość sieci z kolei opisuje stosunek rzeczywistych więzi między jednostkami w danej sieci do więzi potencjalnych. Stanowi miarę tego, jak wielu naszych znajomych i przyjaciół jest również ze sobą powiązanych. Wskazuje się, że wraz z gęstością sieci rośnie presja normatywna wywierana na jednostki. Według niektórych badaczy (zob. Coleman 1988) sieci tego rodzaju są generatorem kapitału społecznego, gdyż domknięcie struktury społecznej sprzyja kontroli, egzekwowaniu norm, mobilizowaniu działań kolektywnych i tworzeniu zaufania - czyli zasobów o charakterze produktywnym. Przeciwieństwem sieci gęstych są sieci zawierające „dziury strukturalne" (structural holes), opisywane przez Ronalda S. Burta (1992) jako struktury, w których jednostka stanowi pośrednik między nieredundantnymi kontaktami (tj. kontaktami, które nie są ze sobą powiązane lub nie są powiązane $z$ jednym źródłem). Bycie pośrednikiem w strukturze relacji sprzyja osiąganiu osobistych korzyści (np. umożliwia dostęp do informacji, kontrolę nad działaniami). Choć nie jest to regułą, otwartość sieci idzie $\mathrm{w}$ parze $\mathrm{z}$ jej zróżnicowaniem, czyli posiadaniem trwałych relacji z osobami o różnych cechach społecznych i zasobach. W tym kontekście można postawić pytanie, jakie właściwości kapitału społecznego sprzyjają jakim formom uczestnictwa w miejskim systemie konsumpcji? Na przykład: czy czynnikiem, który sprzyja aktywności miejskiej, jest posiadanie gęstych i homogenicznych sieci przyjaciół, czy też sieci otwartych i bardziej zróżnicowanych (potencjalnie dających dostęp do większej puli informacji, inspiracji, bodźców do działania itp.)?

Charakterystyka powiązań sieciowych okazała się bardzo trafnym predyktorem przynależności do różnych segmentów zbiorowości mieszkańców (tabela 4). Różnicująca była zwłaszcza liczba kontaktów mierzona tzw. Generatorem Pozycji (Lin 2001). Założono, że znajomość osób z różnych szczebli drabiny stratyfikacyjnej (reprezentowanych przez zawody) 
Sieci społeczne a typy konsumentów (wartości średnie)*

\begin{tabular}{|c|c|c|c|c|c|c|}
\hline \multirow[b]{2}{*}{ Zmienne } & \multicolumn{4}{|c|}{ Typy konsumentów } & \multirow[b]{2}{*}{$\begin{array}{l}\text { Ogó- } \\
\text { łem }\end{array}$} & \multirow[b]{2}{*}{ Eta } \\
\hline & $\begin{array}{l}\text { wyco- } \\
\text { fani }\end{array}$ & $\begin{array}{l}\text { kultu- } \\
\text { ralni }\end{array}$ & $\begin{array}{l}\text { space- } \\
\text { rowi- } \\
\text { cze }\end{array}$ & $\begin{array}{l}\text { gastro- } \\
\text { entu- } \\
\text { zjaści }\end{array}$ & & \\
\hline $\begin{array}{l}\text { Liczba kontaktów (Generator Pozycji); } \\
0-14 \text {; w tym: }\end{array}$ & $\underline{6,75}$ & 11,05 & 8,87 & 8,59 & 9,29 & 0,513 \\
\hline - liczba silnych więzi & $\underline{4,00}$ & 5,47 & 5,00 & 5,27 & 5,08 & 0,201 \\
\hline - liczba słabych więzi & $\underline{2,75}$ & 5,58 & 3,87 & 3,32 & 4,21 & 0,473 \\
\hline $\begin{array}{l}\text { Zróżnicowanie sieci (zmienna standary- } \\
\text { zowana)a }\end{array}$ & $-0,154$ & 0,050 & 0,590 & $-0,309$ & 0,00 & 0,291 \\
\hline Liczba organizacji do jakich należy; 0-3b & 0,189 & 0,833 & 0,174 & 0,358 & 0,490 & 0,297 \\
\hline $\begin{array}{l}\text { Sumaryczna liczba osób, z którymi } \\
\text { utrzymuje się kontakty towarzyskie lub } \\
\text { osobiste; } w \text { tymc: }\end{array}$ & $\underline{9,26}$ & 13,09 & 14,83 & 15,85 & 13,43 & 0,309 \\
\hline - osoby z rodziny & 4,30 & $\underline{3,78}$ & 4,98 & 4,85 & 4,35 & 0,236 \\
\hline - przyjaciele & $\underline{2,58}$ & 4,35 & 3,39 & 5,12 & 4,10 & 0,303 \\
\hline - znajomi & $\underline{2,38}$ & 4,96 & 6,46 & 5,88 & 4,98 & 0,312 \\
\hline $\begin{array}{l}\text { Częstotliwość spotkań towarzyskich } \\
\text { (zmienna standaryzowana)d: }\end{array}$ & & & & & & \\
\hline - $z$ rodziną & $-0,129$ & $-\underline{0,246}$ & 0,347 & 0,252 & 0,00 & 0,251 \\
\hline $\begin{array}{l}\text { - z przyjaciółmi, znajomymi spoza ro- } \\
\text { dziny }\end{array}$ & $-\underline{0,736}$ & $-0,063$ & 0,269 & 0,423 & 0,00 & 0,397 \\
\hline Siła więzi sąsiedzkich (1-6)e & 3,43 & 2,87 & 2,93 & 2,70 & 2,93 & 0,259 \\
\hline Otwartość sieci $(1-5)^{\mathrm{f}}$ & 2,77 & 2,79 & 3,09 & $\underline{2,12}$ & 2,65 & 0,295 \\
\hline
\end{tabular}

* Pogrubioną czcionką zaznaczono wartości najwyższe a podkreśleniami — najniższe.

a Liniowa kombinacja odpowiedzi na osiem pytań mierzących, w jakim stopniu przyjaciele i znajomi różnią się od respondenta (np. z uwagi na: wiek, styl życia, poglądy polityczne).

b Pytanie o przynależność do ,jakichś organizacji, stowarzyszeń (np. zawodowych), partii, komitetów, rad (np. szkolnych), grup religijnych, związków lub kół?” (odpowiedzi: „nie”, „tak, jednej”, „tak, dwóch”, „tak, trzech lub więcej”).

cPytano o osoby, z którymi „utrzymuje się regularnie (przynajmniej kilka razy w roku) kontakty towarzyskie lub osobiste".

dCzęstotliwość spotkań towarzyskich mierzono na sześciopunktowej skali, od 1 — „rzadziej niż raz na rok” do 6 - „raz w tygodniu lub częściej”.

eWięzi sąsiedzkie mierzono na skali od 1 — „nie znam swoich sąsiadów” do 6 — „z wszystkimi lub z większością sąsiadów jestem bardzo zżyty(a); traktuję ich jako jedną, wielką rodzinę".

fOdpowiedź na pytanie o stopień znajomości przyjaciół i bliskich znajomych respondenta między sobą. Odpowiedzi: od 1 - „wszyscy dobrze się znają” do $5-$ „nikt lub prawie nikt nikogo dobrze nie zna".

Źródło: opracowanie własne na podstawie badań mieszkańców Wrocławia. 
odzwierciedla potencjalny zakres zasobów (różnego rodzaju), do których ma się dostęp ${ }^{25}$.

Najbardziej uprzywilejowani pod tym względem byli „kulturalni” (znający średnio 11,05 osób z listy 14 zawodów) w opozycji do „wycofanych” $(\mathrm{M}=6,75)$. Biorąc pod uwagę typ więzi, można zauważyć, iż większą moc dyskryminacyjną mają więzi słabszego typu (operacjonalizowane jako liczba kontaktów o charakterze znajomościowym) ${ }^{26}$. Wielkość sieci „kulturalnych" jest więc rezultatem większej liczby połączeń słabych (podczas gdy liczba więzi silnych jest bardziej wyrównana pomiędzy segmentami). Zgodnie $z$ teorią sieci więzi słabe zwiększają szanse uzyskania nowych zasobów, takich, które nie są dostępne w najbliższym środowisku jednostki (Lin 2001, s. 27). Przedstawiona analiza korelacyjna nie pozwala rozstrzygnąć, czy szerszy udział w kulturze (instytucjonalnej) przejawiany przez „kulturalnych” jest przyczynowo związany bezpośrednio z posiadaniem sieci o większej liczbie alters. Można jednak postawić hipotezę, iż związek taki jest prawdopodobny. Sieci zarówno stanowią źródło informacji i inspiracji, jak i dostarczają „towarzystwa” dla wielu praktyk. Druga hipoteza wydaje się mniej prawdopodobna z uwagi na to, że „kulturalni" nie należą do grona osób szczególnie towarzyskich (zwłaszcza jeśli weźmiemy pod uwagę rodzinę). Ich wzór więzi ma bardziej charakter „publiczny”, o czym świadczy przynależność organizacyjna (kapitał społeczny „formalny”): 36,7\% osób z tej grupy deklarowało, iż jest członkiem jakichś stowarzyszeń, organizacji, partii, komitetów itp., wobec 7,5\% wśród „wycofanych”, 10,9\% wśród „spacerowiczów” i 18,5\% wśród „gastroentuzjastów". Ci ostatni wyróżniali się aktywnością towarzyską (nieformalną) - utrzymywali najwięcej regularnych kontaktów osobistych (w tym z przyjaciółmi) oraz najczęściej się z nimi spotykali. Jeśli dodamy do tego, że ich sieci były najmniej zróżnicowane (tj. najbardziej homogeniczne) oraz cechowała je wysoka gęstość (tj. wewnętrzne powiąza-

${ }^{25}$ Badanym prezentowano listę 14 zawodów/stanowisk z pytaniem, czy wśród ich znajomych, przyjaciół lub w rodzinie są osoby, które je wykonują/zajmują. Chodziło o takie osoby, które się zna na tyle, aby móc nawiązać z nimi swobodny kontakt. Uwzględnione pozycje to prawnik, lekarz, pracownik naukowy wyższej uczelni, nauczyciel, informatyk, przedsiębiorca/właściciel firmy (inny od pracodawcy osoby badanej), lokalny polityk, dziennikarz mechanik, księgowy, artysta/aktor/muzyk, kasjer/sprzedawca, pielęgniarka/pielęgniarz, pracownik budowlany lub robót wykończeniowych. Miarą dostępności do zasobów była liczba pozytywnych wskazań.

${ }^{26}$ Więzi silne mierzono jako sumę kontaktów rodzinnych oraz wśród przyjaciół i bliskich znajomych. 
nia ${ }^{27}$ ), to możemy opisać ich jako uczestniczących w zwartych „klikach” przyjaciół. Ten wzór więzi wydaje się typowy dla młodszych badanych i pozwala wyjaśnić ich umiejscowienie w miejskim polu konsumpcji (nastawienie na rozrywkę, kulturę uliczną, masowość partycypacji). Prawdopodobnie praktyki kulturalne pełnią dla nich funkcję relacjogenną (Szlendak, Goszczyński, Krajewska 2019). Niejako w opozycji do tego segmentu sytuują się „spacerowicze” - posiadacze więzi o luźniejszym charakterze ( $z$ większą liczbą „dziur strukturalnych”) i bardziej heterogenicznych. Grono ich przyjaciół i znajomych tworzą w dużej mierze osoby, które się nie znają, a zarazem osoby różnią się od badanego pod względem społeczno-demograficznym czy kulturowym. Tego rodzaju środowisko społeczne sprzyja indywidualizacji praktyk konsumpcyjnych, gdyż nie stwarza ukierunkowanego nacisku normatywnego. Tłumaczyłoby to, dlaczego „spacerowicze" unikają stylu masowego i wspólnotowego w konsumpcji, a w zamian wybierają praktyki o większym potencjale indywidualizacji (jak piesza turystyka czy spacery). Jednocześnie segment ten jest relatywnie najbardziej prorodzinny, na co wskazuje liczba osób (spoza gospodarstwa), z którymi utrzymuje się kontakty oraz częstotliwość spotkań. Z tej perspektywy ich sieci mają charakter zrównoważony, obejmują zarówno ścisłe relacje, jak i związki przekraczające najbliższe środowisko. To także pozwala zachować im względną autonomię działań.

Spojrzenie na konfigurację powiązań „wycofanych” pozwala wyjaśnić ich model uczestnictwa w mieście. Otóż ten typ miejskiego konsumenta wyróżnia największy deficyt kontaktów społecznych, zwłaszcza tych o dużym potencjale kapitałowym (np. mierzonych Generatorem Pozycji, czy liczbą więzi pozarodzinnych o pomostowym charakterze). Jedynym wskaźnikiem pozytywnie wyróżniającym omawiany segment jest siła więzi sąsiedzkich, mierzonych stopniem zażyłości z osobami mieszkającymi w najbliższym otoczeniu. Podczas gdy 7,4\% „gastroentuzjastów” w ogóle nie zna swoich sąsiadów, a 38,3\% zna ich „tylko z widzenia” (kontakty ograniczają się do grzecznościowego „dzień dobry”), to wśród „wycofanych" jest to odpowiednio 0\% i 18,9\%. Jednocześnie 30,2\% z nich świadczy sobie wzajemnie drobne usługi sąsiedzkie (np. pożyczenie czegoś, popilnowanie domu) (18,5\% wśród „gastroentuzjastów”), a 13,2\% utrzymuje relacje towarzyskie (typu odwiedziny, wspólne spędzanie czasu) (wobec 2,5\% w grupie porównawczej). Wspólnota sąsiedzka stanowi

27 33\% osób z tego segmentu wskazywało, iż wśród przyjaciół i bliskich znajomych „wszyscy dobrze się znają", podczas gdy wśród przedstawicieli pozostałych segmentów ten odsetek wynosił $13-15 \%$. 
tutaj homologiczny odpowiednik praktyk stylu życia zorientowanych na budowanie tożsamości - czy to w instytucjach religijnych, czy też innego rodzaju, jednakże pozostających na marginesie miejskiej „maszyny rozrywki”, która jest domeną osób o ponadprzeciętnych kapitałach (ekonomicznym i kulturowym), zakorzenionych w bogatych sieciach relacji (o różnym charakterze).

W sposób syntetyczny typy miejskich konsumentów na tle zróżnicowań kapitału społecznego przedstawia rysunek 1.

Rysunek 1

Relacje społeczne miejskich konsumentów

\begin{tabular}{|r|l|}
\hline \multicolumn{1}{|c|}{ Wycofani } & \multicolumn{1}{c|}{ Kulturalni } \\
$\begin{array}{l}\text { Silne więzi sąsiedzkie } \rightarrow \text { enklawy wspólnot } \\
\text { Sfziałka, kościół) }\end{array}$ & $\begin{array}{l}\text { Duży kapitał społeczny/zawodowy (Gene- } \\
\text { rator Pozycji) i obywatelski (przynależność } \\
\text { do organizacji) } \\
\text { Sfera publiczna }\end{array}$ \\
\hline $\begin{array}{l}\text { Duże zróżnicóśc sieci } \\
\text { aktywni rodzinnie; mają różne kręgi znajo- } \\
\text { mych (którzy się nie znają) }\end{array}$ & $\begin{array}{l}\text { Domknięcie sieci } \\
\text { Aktywni towarzysko w sferze relacji poza- } \\
\text { rodzinnych; mają zwartą „paczkę przyjaciół” } \\
\text { Spszyscy się znają); najniższe zróżnicowa- } \\
\text { nie sieci }\end{array}$ \\
\hline
\end{tabular}

Źródło: opracowanie własne na podstawie badań mieszkańców Wrocławia.

W polu konsumpcji można odnaleźć nowe wymiary zróżnicowań i antynomii, które są tu opisywane przez opozycje: „sfera prywatna-sfera publiczna” czy „otwartość sieci-domknięcie sieci”. Praktyki składające się na sposób życia (w sferze kultury i konsumpcji) odzwierciedlają praktyki budowania i podtrzymywania kontaktów społecznych, przy czym kierunek tej homologii nie jest określony. Zapewne zarówno kształt więzi społecznych sprzyja „wchodzeniu” do miasta i apropriacji miejskiego kapitału, jak i sam fakt uczestnictwa w miejskim systemie konsumpcji (i związane $z$ tym nagromadzenie kapitału kulturowego) zwrotnie przyczynia się do tworzenia systemu relacji. Zasoby kulturowe (jako zasoby narracji i praktyk) mogą być konwertowane w zasoby kapitału społecznego (Puetz 2015). Sfera stylów życia jest powiązana ze sferą pozycji i stosunków społecznych, jak w przypadku „wycofanych”, wśród których dominantą stylu życia jest odnajdywanie enklaw wspólnot opartych na więziach sąsiedzkich, czy w przypadku "gastroentuzjastów” funkcjonujących na scenach 
miejskiej rozrywki i ulicznej gastronomii dzięki sieciom przyjaciół. Obu stylom życia odpowiadają odmienne wizje „miejskości”: oparta na tradycyjnym ładzie wspólnotowym (bliższa raczej społecznościom wiejskim lub małomiasteczkowym) (Błaszczyk 2017, s. 106) i model kultury doznań i życia towarzyskiego (miasta jako „maszyny rozrywki”), który dominuje w ponowoczesnym społeczeństwie konsumpcyjnym. Styl „kulturalnych” zaś wykazuje największe związki ze sferą publiczną — w zakresie zarówno uczestnictwa w tradycyjnych przybytkach kultury, jak i relacji społecznych (w sferze kontaktów zawodowych i przynależności do organizacji formalnych tworzących społeczeństwo obywatelskie). Daje to „kulturalnym" szerokie możliwości oddziaływania w polu miejskim, nie tylko poprzez włączenie się w dyskurs o kulturze jako ważnym aspekcie życia w mieście, ale także dzięki aktywności organizacyjnej i realnym związkom z elitami władzy. Dość wspomnieć, że w tym segmencie najwięcej jest osób znających „lokalnego polityka” czy „dziennikarza” (odpowiednio $70 \%$ i $68,3 \%$ wobec $9-40 \% \mathrm{w}$ pozostałych segmentach) ${ }^{28}$. Z kolei indywidualizujący styl konsumowania czasu wolnego charakterystyczny dla „spacerowiczów” znajduje przedłużenie w luźnej i „porowatej” strukturze ich więzi. W tym przypadku możliwe są zarówno strategie indywidualnego uczestnictwa w mieście, jak i okazjonalnej zbiorowej mobilizacji w obronie interesów ( $z$ uwagi na posiadany kapitał pomostowy) (por. Putnam 2008).

\section{PODSUMOWANIE}

Współczesne studia miejskie $\mathrm{w}$ coraz większym stopniu ogniskują swój aparat poznawczy na zagadnieniu miejskiej kultury i konsumpcji - rozumianych jako aktywności i zasoby społecznie oraz terytorialnie ustrukturyzowane. Zwrot ku „kulturowym” właściwościom miasta można wiązać z ogólniejszymi przeobrażeniami społecznymi, w tym dotyczącymi bazy ekonomicznej (np. przejściem od epoki fordyzmu do reżimu postfordowskiego), relacji międzyludzkich (np. w obszarze nierówności) czy kultury (w jej ponowoczesnej, konsumpcyjnej odsłonie). Zagadnienie kultury zyskuje centralny status także w refleksji teoretycznej nastawionej na eksplorowanie jej właściwości ustanawiania i budowania połączeń, wspólnot, a także struktur władzy, dominacji i nierówności. Jednocześnie ten „kulturowy zwrot” w analizie miasta dotyczy raczej zagadnień wzro-

${ }^{28}$ Dokładny rozkład odpowiedzi jest następujący: „lokalnego polityka” zna 9,4\% przedstawicieli „wycofanych”, 26,1\% „spacerowiczów” i 30,9\% gastroentuzjastów. „Dziennikarz” jest kontaktem dla 9,4\% „wycofanych”, 39,1\% „spacerowiczów” i 24,7\% „gastroentuzjastów”. 
stu i rozwoju ekonomicznego (np. w postaci analizowania przemysłów kultury i przemysłów kreatywnych) czy miejskiej polityki (kształtowania przestrzeni) niż kwestii sposobów życia mieszkańców. W tym kontekście odniesienie koncepcji teoretycznych Bourdieu, do zagadnień ponowoczesnego miasta i miejskości można potraktować jako próbę socjologicznej rewitalizacji interdyscyplinarnych studiów miejskich, które za sprawą dominacji paradygmatu ekonomicznego i ekologicznego coraz bardziej zbliżają się do zagadnień typowych dla takich dyscyplin jak geografia czy ekonomia. Zastanawia brak (poza nielicznymi wyjątkami ${ }^{29}$ ) bezpośredniego zastosowania teorii francuskiego socjologa w studiach empirycznych dotyczących miasta. Jest to o tyle zaskakujące, że schemat teoretyczny Bourdieu (a zwłaszcza koncepcja miasta jako pola społecznego) jest spójny $z$ nieredukcjonistycznym ujęciem miasta stosowanym przez badaczy o nastawieniu kulturalistycznym. Nawiązuje także, poprzez problematykę stylów i sposobów życia, do klasycznych studiów miejskich (por. Wirth 1938), jednak bardziej realistycznie konceptualizując strukturalny wymiar miejskości, z jego podziałami i nierównościami klasowymi. W dobie kontestowania paradygmatu klasowego (także przez przedstawicieli studiów miejskich, jak Terry N. Clark) koncepcja Bourdieu może dostarczać ważnych argumentów za uznaniem klas za element porządku społecznego, pokazując jak style życia, praktyki, gust i tożsamość pozostają uklasowione, nawet pod nieobecność jawnych tożsamości klasowych.

Miejskie pole konsumpcji jako konfiguracja obiektywnych relacji między pozycjami i dynamiczny obszar gry (toczonej o symboliczne i materialne zawłaszczenie przestrzeni) ukazują wzory praktyk i wykorzystania miejskiej przestrzeni na tle dystrybucji różnych form kapitału, dyspozycji habitusu i przeszłych pozycji w polu ${ }^{30}$. Wyróżnione w analizie style konsumpcji i segmenty konsumentów („wycofani”, „kulturalni”, „spacerowicze”, „gastroentuzjaści”) wykazywały związek z wieloma cechami społeczno-demograficznymi i strukturalnymi osób badanych, w tym z wiekiem (jak w przypadku stylu gastronomiczno-rozrywkowego cechującego młodszych respondentów, w odróżnieniu od stylu wspólnotowego), a zwłaszcza z położeniem społecznym (klasą, zasobami finansowymi, kapitałem kulturowym oraz siecią powiązań). Obraz wyłaniający się z badań ukazuje miejski system konsumpcji jako zdominowany przez kategorie młodszych mieszkańców, osoby o ponadprzeciętnych zasobach kapitału, w tym dys-

${ }^{29}$ Por. artykuły zgromadzone w numerze 1 (tom 42) czasopisma „International Journal of Urban and Regional Research" (2018).

30 Ten ostatni aspekt nie był analizowany w niniejszym opracowaniu. 
ponentów znaczących (choć nie jednakowych) relacji społecznych. Dowodzi to pośrednio, iż przestrzeń miejska modelowana jest właśnie „pod” te kategorie „mieszczan” — w ten sposób „maszyna rozrywki” tworzy i wzmacnia podziały społeczne, które uprzywilejowują jedne klasy i ich sposoby życia (np. klasę kreatywną) kosztem innych kategorii społecznych (Shearmur 2006-2007). Zarazem jednak nawet ci mieszkańcy miasta, którzy zajmowali czołowe pozycje społeczne, od czasu do czasu poszukiwali enklaw stylu życia odległych od kultury konsumpcyjnej w jej skomercjalizowanej formie (czy to w obszarze wspólnot, tak jak „kulturalni”, czy poza miastem jak „spacerowicze”).

Nowym wymiarem analiz była charakterystyka sieci społecznych mieszkańców. Choć obszar ten nie był eksplorowany w klasycznym studium Bourdieu (2005) poświęconym klasowym stylom życia społeczeństwa francuskiego, to przedstawione dane wskazują na jego duży potencjał wyjaśniania zróżnicowań kulturowych. Ogólnie daje się zauważyć homologię między formami kapitału społecznego a charakterem aktywności kulturowo-konsumpcyjnych. Na przykład pozbawieni więzi „zawodowych” i „pomostowych”, zakorzenieni we wspólnocie sąsiedzkiej „wycofani” enklaw stylu życia poszukiwali w przestrzeniach półprywatnych, jak działka czy kościół, podczas gdy posiadający rozległe kontakty „kulturalni” korzystali z szerokiej oferty miejskiego systemu konsumpcji. Związek między kapitałem społecznym (sieciami) a przestrzenią praktyk nie jest jednak jednowymiarowy. Aktywność miejska zależy zarówno od posiadania zwartych sieci przyjaciół (jak w przypadku „gastroentuzjastów”), jak i sieci luźniejszych i heterogenicznych (przypadek „spacerowiczów”). Otwiera to pole do dalszych dociekań, w tym tych dotyczących mechanizmu oddziaływania sieci (np. czy mamy do czynienia z oddziaływaniem informacyjnym, czy też normatywnym i „behawioralnym”?). W przypadku „gastroentuzjastów” można podejrzewać, że gęsta sieć znajomych stanowi bezpośrednie „towarzystwo” podczas wielu czynności czasu wolnego (np. wizyty w pubach, dyskotekach itp.), a „kulturalni” i „spacerowicze” traktują powiązania jako źródło informacji i inspiracji.

Przedstawione wyniki badań nie są wolne od ograniczeń. Jednym z nich jest niereprezentatywny dobór próby badawczej, co utrudnia ekstrapolację wyników na całą społeczność miasta oraz inne (podobne) zbiorowości. Niemniej jednak regularność uzyskanych wyników oraz ich częściowa zbieżność z innymi badaniami (zob. Błaszczyk, Cebula 2016; Błaszczyk 2017) każą przypuszczać, że sformułowane wnioski są uzasadnione, przynajmniej w odniesieniu do dużych miast, charakteryzujących się większą różnorodnością kulturową (zob. Szlendak, Goszczyński, Krajewska 2019). 
Brakuje także pewnych analiz domykających ideę pola Bourdieu. Mowa tu o kategoriach poznawczych, postawach oraz narracjach, w jakich miasto i jego składowe (ludzie, obiekty i miejsca) są opisywane i waloryzowane przez aktorów uczestniczących $\mathrm{w}$ miejskiej grze, zgodnie $\mathrm{z}$ ideą, że nazywanie rzeczywistości w określony sposób jest bronią w walce o ustanawianie i narzucanie dominującej wizji świata (Wacquant 2018, s. 99), jak w przypadku dyskursu o „słoikach” i „osiadłych” mieszkańcach Warszawy (zob. Lewicki, Drozdowska 2017). Także określenie przestrzennego rozlokowania praktyk konsumpcyjnych, pozwoliłoby spojrzeć na miasto jako na sferę „wpływów” i monopolizacji poszczególnych kategorii jego mieszkańców (zob. Hanquinet, Savage, Callier 2012; Savage i in. 2018).

\section{BIBLIOGRAFIA}

Alexander Victoria D., Bowler Anne E., 2014, Editorial. Art at the Crossroads: The Arts in Society and the Sociology of Art, „Poetics”, t. 43, s. 1-19.

Bartkowski Jerzy, 2016, City as an Entertainment Machine (Miasto jako maszyna rozrywki) — koncepcje rozwoju miejskiego i polityki miejskiej Terry'ego Nicholasa Clarka, „Studia Miejskie”, t. 21, s. 117-133.

Baudrillard Jean, 2006, Społeczeństwo konsumpcyjne. Jego mity istruktury, tłum. Sławomir Krulak, Sic!, Warszawa

Bauman Zygmunt, 2006, Praca, konsumpcjonizm i nowi ubodzy, tłum. Stanisław Obirek, WAM, Kraków.

Błaszczyk Mateusz, 2015, Miejski system okazji i jego użytkownicy, „Przestrzeń Społeczna”, nr 1, s. 111-138.

Błaszczyk Mateusz, 2017, Czas wolny, w: Katarzyna Kajdanek, Jacek Pluta (red.), Wroctawska Diagnoza Społeczna 2017. Raport z badań socjologicznych nad mieszkańcami miasta, Wrocław.

Błaszczyk Mateusz, Cebula Michał, 2016, Uczestnictwo w kulturze a uczestnictwo w mieście. O kapitałach kulturowych i różnorodności stylów życia mieszkańców dużego miasta, „Studia Socjologiczne", nr 1, s. 99-126.

Błaszczyk Mateusz, Pluta Jacek (red.), 2015, Uczestnicy, konsumenci, mieszkańcy. Wrocławianie i ich miasto $w$ oglądzie socjologicznym, Scholar, Warszawa.

Bourdieu Pierre, 1983, The Field of Cultural Production, or: The Economic World Reversed, „Poetics”, t. 12 (4-5), s. 311-356.

Bourdieu Pierre, 1985, The Social Space and the Genesis of Groups, „Theory and Society”, t. 14 (6), s. 723-744.

Bourdieu Pierre, 1995, Sociology in Question, Sage Publications, London.

Bourdieu Pierre, 1997, The Forms of Capital, w: A. H. Halsey, Hugh Lauder, Philip Brown, Amy Stuart (red.), Education: Culture, Economy, Society, Oxford University Press, Oxford.

Bourdieu Pierre, 2005, Dystynkcja. Społeczna krytyka władzy sądzenia, tłum. Piotr Biłos, Scholar, Warszawa.

Bourdieu Pierre, 2018, Social Space and the Genesis of the Appropriated Physical Space, „International Journal of Urban and Regional Research", t. 42 (1), s. 106-114. 
Bourdieu Pierre, Wacquant Loïc, 2001, Zaproszenie do socjologii refleksyjnej, tłum. Anna Sawisz, Oficyna Naukowa, Warszawa.

Burt Ronald S., 1992, Structural Holes: The Social Structure of Competition, Harvard University Press, Cambridge.

Burt Ronald S., 2001, Structural Holes versus Network Closure as Social Capital, w: Nan Lin, Karen S. Cook, Ronald S. Burt (red.), Social Capital: Theory and Research, Aldine de Gruyter, New York.

Castells Manuel, 1982, Kwestia miejska, tłum. Bohdan Jałowiecki, Jacek Piątkowski, Państwowe Wydawnictwo Naukowe, Warszawa.

Cebula Michał, 2017, Analiza klasowa na rozdrożu? W stronę kulturowej koncepcji klas P. Bourdieu, „Studia Socjologiczne”, nr 3.

Clark Terry N. (red.), 2003, The City as an Entertainment Machine, Research in Urban Policy, t. 9, Elsevier, Oxford.

Clark Terry N., 2003a, Urban Amenities: Lakes, Opera, and Juice Bars - Do They Drive Development?, w: Terry N. Clark (red.), The City as an Entertainment Machine, Research in Urban Policy, t. 9, Elsevier, Oxford.

Clark Terry N., 2003b, A Political Theory of Consumption, w: Terry N. Clark (red.), The City as an Entertainment Machine, Research in Urban Policy, t. 9, Elsevier, Oxford.

Clark Terry N., Lipset Seymour M. (red.), 2001, The Breakdown of Class Politics: A Debate on Post-Industrial Stratification, The John Hopkins University Press, Baltimore-London.

Coleman James S., 1988, Social Capital in the Creation of Human Capital, „American Journal of Sociology", t. 94 (Supplement), s. 95-120.

Cvetičanin Predrag, Popescu Mihaela, 2011, The Art of Making Classes in Serbia: Another Particular Case of the Possible, „Poetics”, t. 39 (6), s. 444-468.

Domański Henryk, 2007, Struktura społeczna, wydanie nowe, Scholar, Warszawa.

Domański Henryk, Sawiński Zbigniew, Słomczyński Kazimierz M., 2007, Nowa klasyfikacja i skale zawodów. Socjologiczne wskaźniki pozycji społecznej w Polsce, Wydawnictwo IFiS PAN, Warszawa.

Erickson Bonnie H., 1996, Culture, Class, and Connections, „American Journal of Sociology”, t. 102 (1), s. 217-251.

Featherstone Mike, 2001, Koncepcje kultury konsumenckiej, w: Mary Lambkin, Gordon Foxall, Fred van Raaij, Benoît Heilbrunn (red.), Zachowania konsumenta. Koncepcje i badania europejskie, Wydawnictwo Naukowe PWN, Warszawa.

Flemmen Magne, Jarness Vegard, Rosenlund Lennart, 2017, Social Space and Cultural Class Divisions: The Forms of Capital and Contemporary Lifestyles Differentiation, „The British Journal of Sociology", DOI: 10.1111/1468-4446.12295.

Florida Richard, 2010, Narodziny klasy kreatywnej oraz jej wpływ na przeobrażenia $w$ charakterze pracy, wypoczynku, społeczeństwa i życia codziennego, tłum. Tomasz Krzyżanowski, Michał Penkala, NCK, Warszawa.

Florida Richard, Adler Patrick, 2017, The Patchwork Metropolis: The Morphology of the Divided Postindustrial City, ,Journal of Urban Affairs”, DOI: 10.1080/07352166.2017.1360743.

Florida Richard, Gates Gary, 2003, Technology and Tolerance: The Importance of Diversity to High Technology Growth, w: Terry. N. Clark (red.), The City as an Entertainment Machine, Research in Urban Policy, t. 9, Elsevier, Oxford. 
Gans Herbert J., 1962, The Urban Villagers: Group and Class in the Life of Italian-American, Free Press of Glencoe, New York.

Granovetter Mark, 1973, The Strength of Weak Ties, „American Journal of Sociology”, t. 78 (6), s. $1360-1380$.

Hanquinet Laurie, Savage Mike, Callier Louise, 2012, Elaborating Bourdieu's Field Analysis in Urban Studies: Cultural Dynamics in Brussels, „Urban Geography”, t. 33 (4), s. 508-529 .

Hausner Jerzy, Karwińska Anna, Purchla Jacek (red.), 2013, Kultura a rozwój, NCK, Warszawa. Iwasiński Łukasz, 2016, Socjologiczne dyskursy o konsumpcji, WN Katedra, Gdańsk.

Jayne Mark, 2006, Cities and Consumption, Routledge, Taylor \& Francis Group, London-New York.

Kane Danielle, 2004, A Network Approach to the Puzzle of Women's Cultural Participation, „Poetics", t. 32 (2), s. 105-127.

Klekotko Marta, Navarro Clemente J. (red.), 2015, Wymiary kulturowe polskich miast imiasteczek, Wydawnictwo Uniwersytetu Jagiellońskiego, Kraków.

Klekotko Marta, Navarro Clemente J., Clark Terry N., Silver Daniel, 2015, Wymiary i charakter kulturowy miast, w: Marta Klekotko, Clemente J. Navarro (red.), Wymiary kulturowe polskich miast $i$ miasteczek, Wydawnictwo Uniwersytetu Jagiellońskiego, Kraków.

Kotnarowski Michał, Piechocki Przemysław, Płachecki Tomasz, Szlendak Tomasz, 2018, Aktywność kulturalna warszawiaków. Segmentacja. Podsumowanie na podstawie wyników badania uczestnictwa w kulturze w 2017 roku, Miasto Stołeczne Warszawa, Warszawa.

Landry Charles, 2013, Kreatywne miasto: zestaw narzędzi dla miejskich innowatorów, tłum., Olga Siara, NCK, Warszawa.

Lewicki Mikołaj, Drozdowska Adrianna, 2017, „Stoiki” i warszawiacy: klasowe wojny o Warszawę, w: Maciej Gdula, Michał Sutowski (red.), Klasy w Polsce. Teorie, dyskusje, badania, konteksty, ISZ, Warszawa.

Lewicki Mikołaj, Filiciak Mirosław, 2017, Wynalezienie poszerzonego pola kultury, „Kultura i Rozwój”, nr 1 (2), s. 7-31.

Lewis Kevin, Kaufman Jason, Gonzales Marco, Wimmer Andreas, Christakis Nicholas, 2008, Tastes, Ties, and Time: A New Social Network Dataset Using Facebook.com, „Social Networks”, t. 30 (4), s. 330-342.

Lin Nan, 2001, Social Capital: A Theory of Social Structure and Action, Cambridge University Press, Cambridge.

Lizardo Omar, 2006, How Cultural Tastes Shape Personal Networks, „American Sociological Review", t. 71 (5), s. 778-807.

Majer, Andrzej, 2014, Odrodzenie miast, Wydawnictwo Uniewrsytetu Łódzkiego-Scholar, Łódź-Warszawa.

Pakulski Jan, Waters Malcolm, 1996, The Death of Class, Sage Publications, London.

Pluta Jacek, 2018, Uwagi o reprodukcji wspólnoty. Kwestia integracji społecznej mieszkańców miasta poprzez uczestnictwo w kulturze, „Miscellanea Anthropologica et Sociologica”, nr 1, s. 287 $-307$.

Puetz Kyle, 2015, Consumer Culture, Taste Preferences, and Social Network Formation, „Sociology Compass", t. 9 (6), s. 438-449.

Putnam Robert D., 2008, Samotna gra w kręgle. Upadek i odrodzenie wspólnot lokalnych w Stanach Zjednoczonych, tłum. Przemysław Sadura, Sebastian Szymański, WAiP, Warszawa. 
Rosenlund Lennart, 2017, Class Conditions and Urban Differentiation - Applying Distinction's Methodology to the Community, „Bulletin de Méthodologie Sociologique”, t. 135, s. 5-31.

Savage Mike, Hanquinet Laurie, Cunningham Niall, Hjelbrekke Johs, 2018, Emerging Cultural Capital in the City: Profiling London and Brussels, „International Journal of Urban and Regional Research", t. 42 (1), s. 138-149.

Scott Alen J., 2000, The Cultural Economy of Cities: Essays on the Geography of Image-Producing Industries, Sage Publications, London.

Shearmur Richard, 2006-2007, The New Knowledge Aristocracy: The Creative Class, Mobility and Urban Growth, „Work Organisation, Labour and Globalisation”, t. 1 (1), s. 31-47.

Simmel Georg, 2005, Socjologia, tłum. Małgorzata Łukasiewicz, Wydawnictwo Naukowe PWN, Warszawa.

Swartz David L., 2013, Symbolic Power, Politics, and Intellectuals: The Political Sociology of Pierre Bourdieu, University of Chicago Press, Chicago-London.

Szlendak Tomasz, Goszczyński Wojciech, Krajewska Malwina, 2019, Praktyki pozametropolitalne: uczestnictwo w kulturze w małym i średnim mieście, „Studia Socjologiczne”, nr 2, s. 61-98.

Wacquant Loïc, 2018, Bourdieu Comes to Town: Pertinence, Principles, Applications, „International Journal of Urban and Regional Research", t. 42 (1), s. 90-105.

Warde Alan, Tampubolon Gindo, 2002, Social Capital, Networks and Leisure Consumption, „The Sociological Review", t. 50 (2), s. 155-180.

Wirth Louis, 1938, Urbanism as a Way of Life, „American Journal of Sociology”, t. 44 (1), s. 1-24 .

Zukin Sharon, 1998, Urban Lifestyles: Diversity and Standardization in Spaces of Consumption, „Urban Studies”, t. 35 (5-6), s. 825-839.

\title{
URBAN DWELLERS IN THE SOCIAL FIELD: PATTERNS OF PARTICIPATION IN CULTURE, SOCIAL NETWORKS, AND THE CLASS STRUCTURE
}

\author{
Michał Cebula \\ (University of Wrocław)
}

\section{Abstract}

One of the key issues in contemporary urban studies is to consider the city from the perspective of culture and consumption, which are treated as new drivers of urban development and economic prosperity, the essence of urban ways of life, and arenas for the implementation of urban policies. In a consumer society, cities become important nodes where collective and individual consumption takes place on a massive scale. The urban system organizes capabilities and provides the resources for consumption, thus facilitating various kinds of lifestyles. As a result, the urban space operates as an arena of competition, where different consumer orientations and social categories strive physically and symbolically to occupy ground, produce meanings, and create belonging in the spaces and places that constitute the city. In applying Pierre Bourdieu's concept of a "social field," the aim of the article is to show how the space of social positions corresponds to the space of cultural practices. Drawing on the study of cultural and leisure activities in Wrocław, four 
general categories of urban residents are revealed and characterized by their distinct positions in different dimensions of the social space. The analysis also points to social capital (social networks) as an efficient new principle of cultural differentiation. The paper closes with the author's concluding remarks and guidelines for further research.

Key words / słowa kluczowe

urban studies / studia miejskie, lifestyles / style życia, consumption / konsumpcja, social field / pole społeczne, social classes / klasy społeczne, social capital / kapitał społeczny, social networks / sieci społeczne 